\title{
Effect of maternal fluorine intake on breast milk fluorine content
}

\author{
BY S. ESALA* AND E. VUORI \\ Department of Public Health Science, University of Helsinki, Haartmaninkatu 3, \\ SF-00290 Helsinki 29, Finland
}

\author{
AND A. HELLE \\ Institute of Dentistry, University of Helsinki, Kytösuontie 1, SF-00280, \\ Helsinki 28, Finland
}

(Received 4 January 1982 - Accepted 4 March 1982)

\begin{abstract}
1. Breast milk samples were collected from mothers living in areas having an average of 0.2 and $1.7 \mu \mathrm{g}$ fluorine $/ \mathrm{ml}$ in drinking water. The samples were analysed for their ionic and total $\mathrm{F}$ concentrations.

2. Ionic $F$ was determined after microdiffusion by the fluoride-selective electrode. For total $F$ determinations, milk samples were ashed with magnesium succinate fixative, after which the $\mathrm{F}$ concentration was determined as mentioned previously.

3. The median totals for $F$ content of breast milk in the low- and high-F areas were $7.0 \mathrm{ng} / \mathrm{ml}$ (range $4.3-14.0 \mathrm{ng} / \mathrm{ml}$, fifteen mothers) and $10.9 \mathrm{ng} / \mathrm{ml}$ (range $4.5-50.7 \mathrm{ng} / \mathrm{ml}$, nine mothers). The median ionic $\mathrm{F}$ concentrations were $5.0 \mathrm{ng} / \mathrm{ml}$ (range $3.0-6.3 \mathrm{ng} / \mathrm{ml}$, fifteen mothers) and $8.9 \mathrm{ng} / \mathrm{ml}$ (range $<2.0-39.9 \mathrm{ng} / \mathrm{ml}$, nine mothers) respectively. Both the total $\mathrm{F}(0.01>P>0.001)$ and ionic $\mathrm{F}(0.05>P>0.01)$ in breast milk were significantly higher in the high-F area compared to the low-F area.

4. At the ages of 1,2 and 3 months, the calculated average total daily $F$ intakes of exclusively breast-fed infants were 4.8 and $7.3 \mu \mathrm{g} ; 5.0$ and $7.8 \mu \mathrm{g} ; 5.4$ and $8.5 \mu \mathrm{g}$ in the low- and high-F areas respectively.
\end{abstract}

The fluorine intake of infants has received attention in view of two opposite statements; the anticarious effect of $F$ in contrast to a possible $F$ overdose. It has been estimated that infants fed with diluted cows' milk or milk formulas prepared using fluoridated water get fifteen to thirty times more $F$ than breast-fed infants (Ericsson, 1969; Adair \& Wei, 1978). Two viewpoints are evident: some advocate $F$ supplementation soon after birth for infants living in a non-fluoridated community (Tinanoff \& Müller, 1978), while others consider breast milk to be a 'natural standard' in infant feeding and argue firmly against any major deviation from this standard (Ericsson, 1969).

It is still uncertain how breast milk $F$ is affected by raised maternal $F$ intake. Hitherto this has been studied by Dirks et al. (1974), who compared breast milk F concentrations of mothers living in areas having 0.1 and $1.0 \mu \mathrm{g} \mathrm{F} / \mathrm{ml}$ in the drinking water. Breast milk total $F$ concentrations were similar for these two levels of intake, while the ionic $F$ was higher in the high-F area.

In connexion with a study on the quality of Finnish breast milk, efforts were made to solve the effect of maternal $F$ intake on breast milk. This was done by comparing the $F$ content of individual breast milk samples collected from areas with drinking water of both high- and low-F contents.

\section{SUBJECTS AND METHODS}

Breast milk samples were collected from mothers living in two different areas in Finland. In the city of Helsinki (fifteen mothers), drinking water contains $0.2 \mu \mathrm{g} \mathrm{F} / \mathrm{ml}$, in contrast to the area of Elimäki (nine mothers) which has a naturally high $F$ concentration in drinking water, averaging $1.7 \mu \mathrm{g} / \mathrm{ml}$ for the present study.

* Present address: Department of Chemistry, Helsinki University of Technology, Kemistintie 1, SF-02150 Espoo 15, Finland. 
Milk samples were collected as described by Vuori \& Kuitunen (1979). Before sampling, the mothers were advised to wash and dry their nipples. Milk samples were collected manually directly into a polyethylene bottle and stored deep-frozen before analysis. Milk was collected at all feedings over a period of $24 \mathrm{~h}$ before and after each feed. Thus the final milk sample consisted of 'fore' milk and 'hind' milk in equal proportions.

Reproducible analyses of $\mathrm{F}$ in breast milk had previously been done in our laboratory (S. Esala, E. Vuori \& L. Niinistö, unpublished results). Ionic $F$ was separated and concentrated by microdiffusion as hydrofluoric acid $\left(60^{\circ}, 24 \mathrm{~h}\right)$ from a $4 \mathrm{ml}$ sample. The hydrofluoric acid was absorbed into a strip of filter paper treated with sodium hydroxide. After diffusion the paper was eluted with $1 \mathrm{ml}$ of deionized water and $1 \mathrm{ml}$ of acetate buffer and the $\mathrm{F}$ concentration was determined using the fluoride-selective electrode and microsample dishes.

For the determination of total $\mathrm{F}$ concentration, a $5 \mathrm{ml}$ milk sample was freeze-dried and ashed in a platinum crucible using magnesium succinate as fixative. The ashing temperature was raised gradually within an hour and kept at $500-550^{\circ}$ for $3 \mathrm{~h}$. The F concentration of the ashed sample was determined by microdiffusion as described previously.

Each sample was analysed in duplicate on different days. For each set of samples, a blank and a control sample were analysed.

Mothers living in Elimäki each delivered a sample of their drinking water. The $\mathrm{F}$ concentration of the drinking water was determined after adjusting the $\mathrm{pH}$ and ionic strength with TISAB using the fluoride-selective electrode (Orion Research Inc., 1977).

The Wilcoxon rank sum test was employed to test the significance of differences in breast milk $\mathrm{F}$ from the low- and high-F drinking water areas (Colton, 1974).

\section{RESULTS AND DISCUSSION}

The median ionic $\mathrm{F}$ concentrations of breast milk were $5.0 \mathrm{ng} / \mathrm{ml}$ (range $3.0-6 \cdot 3 \mathrm{ng} / \mathrm{ml}$, fifteen samples) and $8.9 \mathrm{ng} / \mathrm{ml}$ (range $<2.0-39.9 \mathrm{ng} / \mathrm{ml}$, nine samples), and total $\mathrm{F}$ concentrations were $7.0 \mathrm{ng} / \mathrm{ml}$ (range $4.3-14.0 \mathrm{ng} / \mathrm{ml}$, fifteen samples) and $10.9 \mathrm{ng} / \mathrm{ml}$ (range $4 \cdot 5-50 \cdot 7 \mathrm{ng} / \mathrm{ml}$, nine samples) in the low- and high-F areas respectively (Fig. 1).

Our values for ionic $\mathrm{F}$ concentrations in breast milk are consistent with values published previously and summarized in Table 1 . The total $\mathrm{F}$ concentrations determined in the present study are somewhat lower than those reported by Dirks et al. (1974) or those analysed in Great Britain (Anon., i977). The present results are, however, compatible with the total F values reported by Ericsson (1969) in Sweden. The differences may be partly due to different maternal $F$ intakes. In Finland the intake of $F$ has been reported to be low, approximately $0.56 \mathrm{mg} / \mathrm{d}$ (Varo et al. 1980).

The fluoride concentration of tap water in Helsinki was $0.2 \mu \mathrm{g} / \mathrm{ml}$. In Elimäki the average fluoride concentration was $1.7 \mu \mathrm{g} / \mathrm{ml}$ with a range of $0.6-2.4 \mu \mathrm{g} / \mathrm{ml}$.

No significant linear correlation between the $F$ concentration of drinking water and of breast milk was found. Using the Wilcoxon rank sum test both the ionic $(0.05>P>0.01)$ and the total $F(0.01>P>0.001)$ contents of breast milk were higher in the high-F area compared with the low-F area. Also, in the low-F area the breast milk $F$ concentration between mothers was very consistent, while in the high-F area the variation of breast milk F concentration from mother to mother was much larger.

Singer \& Armstrong (1960) have suggested that the F concentration in human plasma of individuals living in communities with different levels of $F$ in the drinking water, remains stable until the $\mathrm{F}$ concentration in water exceeds $1.4 \mu \mathrm{g} / \mathrm{ml}$. This statement could easily be applied to breast milk $F$ concentrations as well, because of the similar distribution of $F$ in breast milk and in human plasma (Taves, 1968). This interpretation would also explain why Dirks et al. (1974), who studied breast milk collected from areas having 0.1 and $1.0 \mu \mathrm{g}$ 


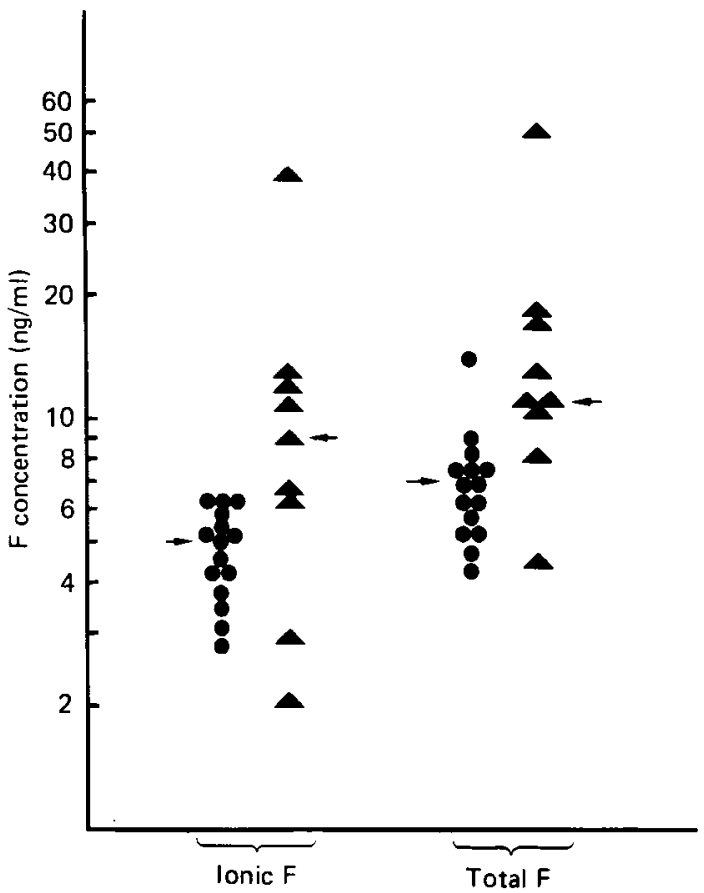

Fig. 1. The ionic and total fluorine concentration of breast milk in Helsinki (O) and Elimäki (A), average 0.2 and $1.7 \mu \mathrm{g} \mathrm{F} / \mathrm{ml}$ in drinking water respectively. $\rightarrow$, Median values.

Table 1. The fluorine concentration $(\mu \mathrm{g} / \mathrm{ml})$ of breast milk as presented in the literature

\begin{tabular}{|c|c|c|c|c|}
\hline \multirow[b]{2}{*}{ Reference and country } & \multirow{2}{*}{$\begin{array}{c}\text { Drinking } \\
\text { water }\end{array}$} & \multicolumn{2}{|c|}{ Breast milk F } & \multirow{2}{*}{$\begin{array}{l}\text { Number of } \\
\text { samples }\end{array}$} \\
\hline & & Ionic & Total & \\
\hline Simpson \& Tuba, 1968 & $0 \cdot 26$ & 0.20 & - & 82 \\
\hline Canada & 1.0 & 0.49 & - & 82 \\
\hline $\begin{array}{l}\text { Ericsson, } 1969 \\
\text { Sweden }\end{array}$ & - & - & $<0.01-0.05$ & - \\
\hline Dirks et al. 1974 & $0 \cdot 1$ & 0.004 & 0.049 & 10 \\
\hline The Netherlands & 1.0 & 0.008 & 0.053 & 9 \\
\hline $\begin{array}{l}\text { Hanhijärvi et al. } 1977 \\
\text { Finland }\end{array}$ & - & 0.011 & - & 3 \\
\hline $\begin{array}{l}\text { Anon., } 1977 \\
\text { Great Britain }\end{array}$ & - & - & 0.077 & $5^{*}$ \\
\hline $\begin{array}{l}\text { Adair \& Wei, } 1978 \\
\text { USA }\end{array}$ & - & $<0.1$ & - & - \\
\hline $\begin{array}{l}\text { Tinanoff \& Müller, } 1978 \\
\text { USA }\end{array}$ & $1 \cdot 0$ & $<0.1$ & - & 1 \\
\hline $\begin{array}{l}\text { Varo et al. } 1980 \\
\text { Finland }\end{array}$ & - & - & 0.1 & $4^{*}$ \\
\hline Present study, 1981 & 0.2 & 0.005 & 0.007 & 15 \\
\hline Finland & $1 \cdot 7$ & 0.009 & $0 \cdot 011$ & 9 \\
\hline
\end{tabular}

* Pooled milk samples. 
$\mathrm{F} / \mathrm{ml}$ in drinking water, did not find any significant difference between the total $\mathrm{F}$ concentration of breast milk from the high- and low-F areas.

The average total daily $\mathrm{F}$ intakes $(\mu \mathrm{g})$ of exclusively breast-fed infants at the age of 1,2 and 3 months respectively, calculated on the basis of the known energy need of normally growing infants and the energy content of breast milk (Vuori, 1979) were $4 \cdot 8$ and $7 \cdot 5,5 \cdot 0$ and $7.8,5.4$ and 8.5 in the low- and high-F areas respectively. All these values are below those recommended by the American Academy of Pediatrics, Committee on Nutrition (1972) for an F intake of $0.5 \mathrm{mg} / \mathrm{d}$ for children from infancy up to 3 years. Our calculated $F$ intake is lower than the dietary intake of bottle-fed infants which has been estimated to be about $320 \mu \mathrm{g} / \mathrm{d}$ at the age of $1-4$ weeks (Wiatrowski et al. 1975). Our results are also lower than the intake of 207-541 $\mu \mathrm{g} \mathrm{F} / \mathrm{d}$ reported by Ophaug et al. (1980) in the USA for a 6-month-old infant consuming a mixed diet.

Breast milk $F$ seems to remain stable as long as the $F$ concentration in the drinking water (or dietary $\mathrm{F}$ intake as a whole) is not very high. Neither does breast milk $\mathrm{F}$ change as a function of the stage of lactation (S. Esala, E. Vuori \& L. Niinistö, unpublished results). This might point to some kind of regulating system in the excretion of $F$ in breast milk. The low-F intake of infants must therefore be considered a physiological phenomenon.

\section{REFERENCES}

Adair, S. M. \& Wei, S. H. Y. (1978). Caries Res. 12, 76.

American Academy of Pediatrics, Committee on Nutrition (1972). Pediatrics, Springfield 49, 456.

Anon. (1977). The Composition of Mature Human Milk. Report on Health and Social Subjects no. 12. London: HMSO.

Colton, T. (1974). Statistics in Medicine, p. 221. Boston: Little, Brown \& Co.

Dirks, O. B., Jongeling-Eijndhoven, J. M. P. A., Flissebaalje, T. D. \& Gedalia, I. (1974). Caries Res. 8, 181.

Ericsson, Y. (1969). Caries Res. 3, 159.

Hanhijärvi, H., Erkkola, R. \& Kanto, J. (1977). Fluoride 10, 169.

Ophaug, R. H., Singer, L. \& Harland, B. F. (1980). Am. J. clin. Nutr. 33, 324.

Orion Research Inc. (1977). Instruction Manual. Helsinki: Orion Research Inc.

Simpson, W. J. \& Tuba, J. (1968). J. Oral Med. 23, 104.

Singer, L. \& Armstrong, J. (1960). J. appl. Physiol. 15, 508.

Taves, D. R. (1968). Nature, Lond. 217, 1050.

Tinanoff, N. \& Müller, B. (1978). J. Dent. Child. 45, 53.

Varo, P., Nuurtamo, M., Saari, E. \& Koivistoinen, P. (1980). Acta Agric. scand. 22, Suppl., 115.

Vuori, E. (1979). Br. J. Nutr. 42, 407.

Vuori, E. \& Kuitunen, P. (1979). Acta Paediat. scand. 68, 33.

Wiatrowski, E., Kramer, L., Osis, D. \& Spencer, H. (1975). Pediatrics, Springfield 55, 517. 